\title{
Does serum homocysteine level have a role in the early pregnancy loss?
}

\author{
Fatih Şanlıkan' (D), Fatma Tufan Altuncu² (D), Koray Özbay' (D), \\ Muhittin Eftal Avci ${ }^{3}$ iD), Ahmet Göçmen ${ }^{1}$ \\ ${ }^{1}$ Clinic of Obstetrics and Gynecology, Şişli Memorial Hospital, Istanbul, Turkey \\ ${ }^{2}$ Eskişehir Mahmudiye Primary Care Center, Eskişehir, Turkey \\ Clinic of Obstetrics and Gynecology, Antalya Memorial Hospital, Antalya, Turkey
}

\begin{abstract}
Objective: To investigate the relationship between high maternal homocysteine levels and early pregnancy losses.

Methods: Seventy patients diagnosed with miscarriage (missed, incomplete and threatened) between 5 and 12 weeks of gestation and 54 pregnant women without any problem during their follow-up were compared in terms of homocysteine levels during pregnancy.

Results: The highest mean serum homocysteine level among the miscarriage groups was in the threatened miscarriage group $(8.9 \pm 3.9$ $\mathrm{nmol} / \mathrm{l}$ ), followed by $7.8 \pm 2.5$ and $8.7 \pm 4.2 \mathrm{nmol} / \mathrm{l}$ in the missed and incomplete miscarriage groups, respectively. The mean serum homocysteine level in the control group was $4.8 \pm 0.9 \mathrm{nmol} / \mathrm{l}$. The homocysteine levels of the control group were significantly lower than all three miscarriage groups $(\mathrm{p}<0.01)$. On the other hand, there was no significant difference between the homocysteine levels of the miscarriage groups $(\mathrm{p}>0.05)$. When compared to the control group, the most significant difference among the serum homocysteine levels was found in the missed miscarriage $(\mathrm{p}<0.01)$.

Conclusion: High homocysteine levels detected during early weeks of gestation can be a warning about the miscarriage risk, and also may provide insight about the obstetric complications that may develop in the further weeks of gestation such as preeclampsia, ablatio placentae and intrauterine growth restriction.
\end{abstract}

Keywords: Homocysteine, pregnancy, early pregnancy loss, miscarriage.

\section{Introduction}

Pregnancy loss or miscarriage is a definition used for the non-viable pregnancies up to 20 weeks of gestation. Usually, the term of early pregnancy loss is used for the loss of 12-week and 6-day pregnancies as from the last
Özet: Erken gebelik kayıplarında serum homosistein düzeyinin rolü var mıdır?

Amaç: Yüksek maternal homosistein düzeyleri ile erken gebelik kayıpları arasındaki ilişkiyi araşıırmak.

Yöntem: 5-12. gebelik haftaları arasında abortus (misssed, inkomplet ve imminens) tanisı alan 70 hasta, takiplerinde sorun olmayan 54 gebe ile gebe homosistein düzeyleri açısından karşılaştırıldı.

Bulgular: Abortus gruplarında en yüksek serum homosistein düzeyi ortalaması abortus imminens grubunda tespit edildi $(8.9 \pm 3.9$ $\mathrm{nmol} / \mathrm{l})$, bu ortalama missed abortus ve inkomplet abortus gruplarinda sırasıyla $7.8 \pm 2.5$ ve $8.7 \pm 4.2 \mathrm{nmol} / \mathrm{l}$ olarak bulundu. Kontrol grubunda serum homosistein düzeyi ortalaması $4.8 \pm 0.9 \mathrm{nmol} / \mathrm{l}$ olarak saptand. Kontrol grubunun homosistein düzeyleri her üç abortus grubundan anlamlı düzeyde düşüktü $(\mathrm{p}<0.01)$. Abortus gruplarının homosistein düzeyleri arasında ise anlamlı farklılık yoktu ( $>0.05)$. Kontrol grubu ile karşılaştırıldığında serum homosistein düzeyleri arasında en anlamlı fark missed abortus grubunda saptandi $(\mathrm{p}<0.01)$.

Sonuç: Erken gebelik haftalarında tespit edilen yüksek homosistein düzeyleri, abortus riski hakkında uyarıcı olabileceği gibi ilerleyen haftalarda gelişebilecek olan preeklampsi, plasenta dekolmanı ve intrauterin gelişme geriliği gibi obstetrik komplikasyonlar hakkında da fikir verebilir.

Anahtar sözcükler: Homosistein, gebelik, erken gebelik kaybı, abortus.

menstrual period. ${ }^{[1]}$ Eighty percent of the miscarriages are seen as early pregnancy loss. The incidence decreasing down to $10 \%$ in the patients with clinically confirmed pregnancies, it increases up to $31 \%$ when the pregnancies unnoticed in the first trimester are includ-

Correspondence: Fatih Şanlıkan, MD. Clinic of Obstetrics and Gynecology, Şişli Memorial Hospital, Şişli, Istanbul, Turkey.

e-mail: fatihroland@hotmail.com / Received: November 21, 2019; Accepted: December 31, 2019

Please cite this article as: Şanlıkan F, Tufan Altuncu F, Özbay K, Avcı ME, Göçmen A. Does serum homocysteine level have a role in the early pregnancy loss? Perinatal Journal 2019;27(3):189-193. doi:10.2399/prn.19.0273011 
ed. ${ }^{[2]}$ Pregnancy at advanced maternal age, history of miscarriage, maternal obesity, thyroid diseases, diabetes, stress, hereditary thrombophilia, use of teratogenic drug-substance and subchorionic hematoma are among the risk factors of early pregnancy losses. According to the results of a meta-analysis consisting of 40 studies on the use of multivitamin and during pregestational period and early weeks of gestation, it was shown that the use of vitamin could not prevent early pregnancy losses. ${ }^{\left[{ }^{3]}\right.}$ There are few numbers of studies on the impacts of molecules such as homocysteine associated with the folic acid and metabolism on the miscarriage etiology.

Homocysteine is a non-proteinogenic amino acid which includes sulfur and biosynthesized from methionine by the removal of its terminal methyl group. It is recycled to methionine via folic acid and vitamin B12. Methylene-tetrahydrofolate-reductase (MTHFR) is needed for this recycling process called remethylation. Homocysteine also can be converted to cysteine through transsulfuration pathway with the help of pyridoxal 5'-phosphate which is the active form of vitamin B6. The hereditary lack of cystathionine-B-synthase enzyme which may affect homocysteine metabolism, homozygote mutations in MTHFR gene, deficiencies of folate, and vitamin B12 and vitamin B6 due to malnutrition lead to hyperhomocysteinemia. There are many studies showing the association of vasculopathy and cardiovascular diseases with the increased homocysteine levels due to some disorders in the homocysteine metabolism. ${ }^{[4-6]}$ There are also studies reporting that the hyperhomocysteinemia is an independent risk factor for preeclampsia and the rates of neural tube defects are higher in the pregnant women who have high homocysteine levels due to folic acid deficiency. ${ }^{[4,7,8]}$ It was shown that the hyperhomocysteinemia may lead to intrauterine growth restriction, impaired placenta function and ablatio placentae due to vascular endothelial dysfunction; the free oxygen radicals produced as a result of homocysteine oxidation damage vascular endothelium directly and high homocysteine levels have a thrombotic impact on the coagulation cascade in the endothelium..$^{[9]}$

There are studies suggesting that the mild and medium levels of hyperhomocysteinemia is an independent risk factor for occlusive arterial and venous disease and it is associated with the patients with unexplained recurrent pregnancy loss. ${ }^{[10]}$
We aimed to investigate the relationship between maternal serum homocysteine level and early pregnancy loss in our study.

\section{Methods}

The pregnant women between 5 and 12 weeks of gestation who were diagnosed with miscarriage in the Clinic of Obstetrics and Gynecology of Ümraniye Training and Research Hospital, Istanbul were included in the study group. The patients who were diagnosed with miscarriage for the first time $(n=70)$ were separated into 3 sub-groups. The patients $(n=17)$ with fetus or placenta tissues remained in the uterus partially and whose vaginal bleeding continued were included in the incomplete miscarriage group, the patients $(n=17)$ whose cervix was closed but had bleeding and with viable pregnancy according to the ultrasonography were included in the threatened miscarriage, and the patients $(n=26)$ without any indication of loss but fetus did not have any fetal cardiac activity were included in the missed miscarriage. Fifty-four pregnant women without any problem during their follow-up in the first trimester were included in the control group. The presence of known infection, consanguineous marriage, the history of recurrent pregnancy loss in the family, the presence of hypothyroidism, the history of personal or familial deep vein thrombosis, the history of neural tube defect, hypertension, and the history of consuming alcohol and smoking were the exclusion criteria and such cases were excluded from the study. In the group with miscarriage diagnosis, 5 patients with smoking habit, 2 patients with the history of recurrent pregnancy loss, 2 patients with consanguineous marriage and 1 patient with hypothyroidism were excluded from the study. The groups were compared in terms of age, gravida, parity, hemoglobin, hematocrit, vitamin B12, folate levels, week of gestation and homocysteine levels. The informed consents of the patients in both groups were obtained. The study was approved by the Ethics Committee of the hospital.

$5 \mathrm{ml}$ venous blood was collected from the patients in the study and control groups. The collected venous blood samples were transferred to ethylenediamine tetra-acetate (EDTA) tubes and centrifuged at 3000 rpm for 10 minutes. The plasm samples were stored at $-20^{\circ} \mathrm{C}$ until they were used. The homocysteine levels were analyzed with Immulite 2000 Immunoassay System (Siemens, Erlangen, Germany). 
The statistical analyses were performed by SPSS 20 (SPSS Inc., Chicago, IL, USA). The descriptive statistical analyses (mean, standard deviation, range) were used when assessing the study data. When comparing the data, Kolmogorov-Smirnov and Student t-test were used in two groups and one-way ANOVA and post-hoc Tukey HDS tests in multiple groups. The results were assessed in $95 \%$ confidence interval and with $\mathrm{p}<0.05$ significance level.

\section{Results}

The study was conducted with a total of 114 cases. The ages of the cases were varying between 20 and 39, and the mean age was $28.24 \pm 3.89$. Seventeen threatened miscarriage cases, 26 missed miscarriage cases, 17 incomplete miscarriage cases and 54 cases which did not develop miscarriage were included in the study. The cases in missed and incomplete miscarriage groups were the patients with isolated single fetal losses. There was no statistical difference between the miscarriage and control groups in terms of age, gravida, parity, hemoglobin and hematocrit values (Table 1). No difference was found between the groups in terms of serum vitamin B12 values; there was no statistically significant difference between the groups in terms of serum folate and homocysteine values. In the post-hoc Tukey HSD test performed to identify which group had the significance, homocysteine levels of the control group were found significantly lower than all three miscarriage groups $(p<0.01)$. The highest mean serum homocysteine level among the miscarriage groups was found in the threat- ened miscarriage group $(8.9 \pm 3.9 \mathrm{nmol} / \mathrm{l})$; it was $7.8 \pm 2.5$ and $8.7 \pm 4.2 \mathrm{nmol} / 1$ in the missed and incomplete groups, respectively. Mean serum homocysteine level was $4.8 \pm 0.9 \mathrm{nmol} / 1$ in the control group. In the sub-group analysis, it was found that serum folate level was $15.6 \pm 8.3$ and $9.9 \pm 5.6 \mathrm{ng} / \mathrm{ml}$ in the threatened miscarriage and missed miscarriage groups, and the difference was not statistically significant $(\mathrm{p}=0.02)$. On the other hand, there was no significant difference between the homocysteine levels of the miscarriage groups ( $>0.05)$. When compared to the control group, the most significant difference between the serum homocysteine levels was in the missed miscarriage group $(\mathrm{p}=0.001)$.

\section{Discussion}

Homocysteine is a significant amino acid which has a significant role in the gestational physiology and is synthesized from the methionine taken primarily through nutrition. The clinical studies indicate that high homocysteine levels may cause serious gestational diseases. Free oxygen radicals produced as a result of homocysteine oxidation have a toxic effect on the vascular endothelium. ${ }^{[5,11]}$ Also, high homocysteine levels impair the coagulation cascade and increase the affinity of endothelium, which is anti-thrombotic, to thrombosis more under normal circumstances. ${ }^{[9]}$ High homocysteine levels, which is toxic for the vascular endothelium in terms of placental microvascularization, embryo implantation and maternal-fetal circulation, are also among the factors which may lead to preeclampsia, recurrent pregnancy loss and intrauterine growth restriction. ${ }^{[12]}$ In our

Table 1. Demographic characteristics and measured serum biomarkers of the patients

\begin{tabular}{|c|c|c|c|c|c|}
\hline & $\begin{array}{l}\text { Threatened miscarriage } \\
\qquad n=17 \\
\text { mean } \pm S D(\text { min-max })\end{array}$ & $\begin{array}{l}\text { Missed miscarriage } \\
\qquad n=26 \\
\text { mean } \pm \text { SD (min-max) }\end{array}$ & $\begin{array}{l}\text { Incomplete miscarriage } \\
\qquad n=17 \\
\text { mean } \pm S D(\text { min-max })\end{array}$ & $\begin{array}{c}\text { Control group } \\
n=54 \\
\text { mean } \pm S D \text { (min-max) }\end{array}$ & p-value \\
\hline Age & $26.76 \pm 5.1(21-38)$ & $28.77 \pm 4.9(20-36)$ & $29.5 \pm 4.3(22-39)$ & $28.0 \pm 2.3(23-32)$ & 0.162 \\
\hline Gravida & $2.4 \pm 0.8(1-4)$ & $2.5 \pm 0.6(2-4)$ & $2.8 \pm 0.8(1-4)$ & $2.2 \pm 0.7(1-4)$ & 0.052 \\
\hline Parity & $1.4 \pm 0.7(0-3)$ & $1.5 \pm 0.6(1-3)$ & $1.8 \pm 0.2(0-3)$ & $1.2 \pm 0.1(0-3)$ & 0.051 \\
\hline Hemoglobin ( $g / d l)$ & $11.6 \pm 0.9(10-13.9)$ & $11.0 \pm 1.8(8.9-14.1)$ & $11.8 \pm 1.2(9-14)$ & $12.1 \pm 1.1(9.6-14.8)$ & 0.006 \\
\hline Hematocrit (\%) & $34.3 \pm 5.6(14-38.1)$ & $33.7 \pm 5.1(28-42.7)$ & $37.1 \pm 3.3(28-43.6)$ & $36.7 \pm 4.3(13.5-42.8)$ & 0.016 \\
\hline Serum folate (ng/ml) & $15.6 \pm 8.3(7-41.9)$ & $9.9 \pm 5.6(4-20)$ & $11.7 \pm 4.9(5.7-20)$ & $13.1 \pm 3.0(6.63-21)$ & 0.003 \\
\hline Serum vitamin B12 (pg/ml) & $237.3 \pm 97.8(118-453)$ & $255.5 \pm 90.4(52-415.4)$ & $245.3 \pm 71(125.7-446)$ & $307.7 \pm 11.9(132.3-684)$ & 0.023 \\
\hline Serum homocysteine ( $\mathrm{nmol} / \mathrm{l})$ & $8.9 \pm 3.9(2.2-16.6)$ & $7.8 \pm 2.5(3.1-15.8)$ & $8.7 \pm 4.2(3.2-16.4)$ & $4.8 \pm 0.9(2-6)$ & 0.001 \\
\hline
\end{tabular}


study, we investigated whether homocysteine, which may cause serious obstetric problems with high levels, has a role in the early pregnancy losses or not.

Plasma homocysteine level reaches its lowest value in the second trimester and reduces during pregnancy significantly. Walker et al. investigated homocysteine levels during pregnancy and found that the homocysteine level was $5.6 \mu \mathrm{mol} / \mathrm{L}$ at $8-16$ weeks, $4.3 \mu \mathrm{mol} / \mathrm{L}$ at $20-28$ weeks, and $5.5 \mu \mathrm{mol} / \mathrm{L}$ at $36-42$ weeks. It was $7.9 \mu \mathrm{mol} / \mathrm{L}$ in the non-pregnant control group. ${ }^{[13]}$

In our study, the homocysteine level was 4.9 $\mu \mathrm{mol} / \mathrm{L}$ in the normal early pregnancy group, which was consistent with the literature, and $8.42 \mu \mathrm{mol} / \mathrm{L}$ in the miscarriage group which was significantly different $(\mathrm{p}<0.001)$.

Hyperhomocysteinemia is defined as the plasma fasting homocysteine levels being higher than 95th percentile and its threshold value is determined 18.3 $\mu \mathrm{mol} / \mathrm{L}$ in the literature. ${ }^{[14]}$ The homocysteine level we found in the miscarriage group was not reaching to the hyperhomocysteinemia level defined in the literature; however, it was higher than the control group in a statistically significant manner.

The impaired chorion villus vascularization is associated with the embryonic death. Nelen et al. investigated the maternal homocysteine levels and the chorionic vascularization in the miscarriage materials, and observed that the chorionic vascular systems of the women with normal homocysteine levels developed better and had less fibrosis and intervillous fibrine deposits. ${ }^{[15]}$ They found that high maternal homocysteine levels were associated with defective chorionic villus vascularization in the cases with recurrent early pregnancy loss as a similar finding. ${ }^{[13]}$ Mild and medium levels of hyperhomocysteinemia is an independent risk factor for occlusive arterial and venous diseases. ${ }^{[16]}$ In the light of this information, it can be considered that hyperhomocysteinemia impairs placental function or maternal uteroplacental perfusion and causes miscarriage. Therefore, we may consider that homocysteine levels higher in the miscarriage cases than the pregnancies with normal progression may have an impact on the pathology. It is possible to think that the damage and occlusion in decidual or chorionic vessels due to the high homocysteine levels in the threatened miscarriage cases may impair the implantation of gestational product and we may clinically meet such cases as bleed- ing complaints due to the necrosis as a result. Also, it was demonstrated in vitro that L-homocysteine was embryotoxic. ${ }^{[17]}$

It is known that cobalamin and folate levels are lower in the women with high total homocysteine concentrations. ${ }^{[14,15]}$ Sikora et al. found negatively high correlation between folic acid levels and homocysteine concentrations in the recurrent miscarriage cases $(r=-0.5397$, $\mathrm{p}<0.01) .{ }^{[18]}$ Similarly, Wouters et al. found a negatively significant correlation between serum and erythrocyte folate levels and total homocysteine concentrations in the recurrent miscarriage cases $(r=-0.3$ and -0.4 , respectively), and they also found a negatively significant correlation between serum vitamin B12 levels and total homocysteine concentrations $(r=-0.5) .{ }^{[19]}$ In our study, we found a negative correlation between folic acid and vitamin B12 levels and homocysteine levels in the missed miscarriage and incomplete miscarriage groups ( $\mathrm{r}=-0.1$ and $r=0.2$ ). These findings were consistent with the literature.

It was reported that folic acid support decreases homocysteine level in the pregnancy. ${ }^{[13]}$ Folic acid support may be beneficial in the cases with early pregnancy losses. ${ }^{[14]}$ Vitamin B6 and B12 supplement in addition to the therapeutic doses of folic acid is recommended during pregestational period is recommended in order to prevent recurrent pregnancy losses. ${ }^{[18]}$ There is no certain data in the literature about the routine use of folic acid to prevent miscarriage, which is recommended to prevent neural tube defects in the preconceptional period and in the early weeks of gestation.

Hoffman et al. reported that abnormal folate metabolism is not a distinct risk factor for the first trimester spontaneous miscarriages. In their studies, they included 13 cases, who underwent curettage due to miscarriage in the first trimester, in the study group and 15 cases in the control group, and they found mean homocysteine level $5.8 \mu \mathrm{mol} / \mathrm{L}$ in the study group and $5.7 \mu \mathrm{mol} / \mathrm{L}$ in the control group, but they did not find any certain significance between the groups $(\mathrm{p}=0.83){ }^{[20]}$ However, unlike these results, we found higher homocysteine levels in the study group compared to the control group. We believe that the number of cases in our study group higher than those in the study group $(n=60)$ of Hoffman et al. may be the reason of this difference in the results. Our results indicate that the homocysteine levels higher than the normal levels may have a role in the first trimester miscarriage cases. 


\section{Conclusion}

A balanced homocysteine metabolism is very important for maternal and fetal health during pregestational and gestation periods. Although it is not recommended to measure serum homocysteine levels in the early weeks of gestation as a routine practice, it may provide an insight about miscarriage when high levels are detected, and it can be a warning about the serious obstetric complications that may develop in the further weeks of gestation such as preeclampsia, ablatio placentae and intrauterine growth restriction.

Conflicts of Interest: No conflicts declared.

\section{References}

1. ACOG Practice Bulletin No. 200 Summary: early pregnancy loss. Obstet Gynecol 2018;132:1311-3.

2. Magnus MC, Wilcox AJ, Morken NH, Weinberg CR, Håberg SE. Role of maternal age and pregnancy history in risk of miscarriage: prospective register based study. BMJ 2019;364:1869.

3. Gindler J, Li Z, Berry RJ, Correa A, Sun X, Wong L, et al.; Jiaxing City Collaborative Project on Neural Tube Defect Prevention. Folic acid supplements during pregnancy and risk of miscarriage. Lancet 2001;358:796-800.

4. Hekmati Azar Mehrabani Z, Ghorbanihaghjo A, Sayyah Melli M, Hamzeh-Mivehroud M, Fathi Maroufi N, Bargahi N, et al. Effects of folic acid supplementation on serum homocysteine and lipoprotein (a) levels during pregnancy. Bioimpacts 2015; 5:177-82.

5. Sukumar N, Adaikalakoteswari A, Venkataraman H, Maheswaran H, Saravanan P. Vitamin B12 status in women of childbearing age in the UK and its relationship with national nutrient intake guidelines: results from two National Diet and Nutrition Surveys. BMJ Open 2016;6:e011247.

6. Barnabé A, Aléssio AC, Bittar LF, de Moraes Mazetto B, Bicudo AM, de Paula EV, et al. Folate, vitamin B12 and homocysteine status in the post-folic acid fortification era in different subgroups of the Brazilian population attended to at a public health care center. Nutr J 2015;14:19.

7. Ocal P, Ersoylu B, Cepni I, Guralp O, Atakul N, Irez T, et al. The association between homocysteine in the follicular fluid with embryo quality and pregnancy rate in assisted reproductive techniques. J Assist Reprod Genet 2012;29:299-304.

8. Sayyah-Melli M, Ghorbanihaghjo A, Alizadeh M, KazemiShishvan M, Ghojazadeh M, Bidadi S. The effect of high dose folic acid throughout pregnancy on homocysteine (Hcy) con- centration and pre-eclampsia: a randomized clinical trial. PLoS One 2016;11:e0154400.

9. Gaiday AN, Tussupkaliyev AB, Bermagambetova SK, Zhumagulova SS, Sarsembayeva LK, Dossimbetova MB, et al. Effect of homocysteine on pregnancy: a systematic review. Chem $\mathrm{Bi}-$ ol Interact 2018;293:70-6.

10. Wouters MG, Boers GH, Blom HJ, Trijbels FJ, Thomas CM, Borm GF, et al. Hyperhomocysteinemia: a risk factor in women with unexplained recurrent early pregnancy loss. Fertil Steril 1993;60:820-5.

11. Zeng Y, Li M, Chen Y, Wang S. Homocysteine, endothelin-1 and nitric oxide in patients with hypertensive disorders complicating pregnancy. Int J Clin Exp Pathol 2015;8:15275-9.

12. Sun F, Qian W, Zhang C, Fan JX, Huang HF. Correlation of maternal serum homocysteine in the first trimester with the development of gestational hypertension and preeclampsia. Med Sci Monit 2017;23:5396-401.

13. Walker MC, Smith GN, Perkins SL, Keely EJ, Garner PR. Changes in homocysteine levels during normal pregnancy. Am J Obstet Gynecol 1999;180:660-4.

14. Nelen WL, Blom HJ, Steegers EA, den Heijer M, Thomas $\mathrm{CM}$, Eskes TK. Homocysteine and folate levels as risk factors for recurrent early pregnancy loss. Obstet Gynecol 2000;95: 519-24.

15. Nelen WL, Bulten J, Steegers EA, Blom HJ, Hanselaar AG, Eskes TK. Maternal homocysteine and chorionic vascularization in recurrent early pregnancy loss. Hum Reprod 2000;15: 954-60.

16. Quere I, Bellet H, Hoffet M, Janbon C, Mares P, Gris JC. A woman with five consecutive fetal deaths: case report and retrospective analysis of hyperhomocysteinemia prevalence in 100 consecutive women with recurrent miscarriages. Fertil Steril 1998;69:152-4.

17. van Aerts LA, Klaasboer HH, Postma NS, Pertijs JC, Copius Peereboom JH, Eskes TK, et al. Stereospecific in vitro embryotoxicity of 1-homocysteine in pre- and post-implantation rodent embryos. Toxicol In Vitro 1993;7:743-9.

18. Sikora J, Magnucki J, Zietek J, Kobielska L, Partyka R, Kokocinska D, et al. Homocysteine, folic acid and vitamin B12 concentration in patients with recurrent miscarriages. Neuro Endocrinol Lett 2007;28:507-12.

19. Wouters MG, Boers GH, Blom HJ, Trijbels FJ, Thomas CM, Borm GF, et al. Hyperhomocysteinemia: a risk factor in women with unexplained recurrent early pregnancy loss. Fertil Steril 1993;60:820-5.

20. Hoffman ML, Scoccia B, Kurczynski TW, Shulman LP, Gao W. Abnormal folate metabolism as a risk factor for first-trimester spontaneous abortion. J Reprod Med 2008;53:20712.

Bu makalenin kullanım izni Creative Commons Attribution-NoCommercial-NoDerivs 3.0 Unported (CC BY-NC-ND3.0) lisansı aracılı̆̆gyla bedelsiz sunulmaktadir. / This work is licensed under the Creative Commons Attribution-NonCommercial-NoDerivs 3.0 Unported (CC BY-NC-ND3.0) License. To view a copy of this license, visit http://creativecommons.org/licenses/by-nc-nd/3.0/ or send a letter to Creative Commons, PO Box 1866 , Mountain View, CA 94042, USA. 